\title{
DEKONSTRUKSI MAKNA TRANSAKSI DALAM AKUNTANSI: SUATU PENDEKATAN IDEALISME SYARIAH ISLAM
}

\author{
Robinson \\ FEB Universitas Bengkulu \\ (robin76kph@gmail.com)
}

\begin{abstract}
Abstrak
Sesuai dengan fungsi filsafat yakni merumuskan kembali muatan moral dan nilai bagi landasan bangunan sains modern, maka akuntansi sebagai bagian dari sains dan teknologi juga harus merumuskan kembali muatan-muatan moral dan nilai dalam kerangka pengetahuan akuntansi tersebut. Salah satu upaya yang dapat dilakukan untuk merumuskan muatan moral dan nilai dalam akuntansi, yakni dengan memasukkan unsur-unsur nilai moral dalam setiap makna dari definisi akuntansi. Salah satu kata kunci dari definisi akuntansi adalah transaksi, dimana transaksi menjadi dasar apa yang akan dicatat, diikhtisar dan dilaporkan. Sehingga sangat penting untuk memastikan makna dari suatu transaksi, serta muatan nilai dan moral didalamnya, apakah suatu kejadian memenuhi kriteria sebagai suatu transaksi atau tidak akan menentukan apakah dapat diproses secara akuntansi atau tidak.

Makalah ini mencoba untuk merumuskan muatan moral dan nilai dalam lingkup makna transaksi yang merupakan dasar adanya praktik pencatatan serta proses selanjutnya dalam akuntansi. Adapun sumber utama dari muatan moral dan nilai adalah dari ajaran agama (dalam makalah ini merujuk pada ajaran agama Islam). Makna transaksi dalam pandangan Islam dapat di dekonstruksi menjadi suatu akad (tentang kejadian ekonomi) terhadap barang/jasa yang melibatkan dua pihak atau lebih, dimana baik akad, objek maupun pelakunya harus memenuhi rukun dan syarat transaksi sesuai dengan syariat Islam.

Pelaku transaksi, dalam suatu transaksi harus jelas keberadannya serta memenuhi kriteria diantaranya adalah berakal. Selain itu menurut syariat Islam pelaku transaksi tidak boleh melanggar prinsip menzhalimi dan dizhalimi serta tidak diperbolehkan menciptakan ketidakpastian (gharar). Sesuai rukun transaksi dalam syriat Islam, objek transaksi harus jelas keberiadaannya serta tidak boleh melanggar prinsip halal dan haramnya. Selain itu, objek yang ditransaksikan juga tidak boleh mengandung ketidakpastian dari segi harga, kualitas, kuantitas dan waktu. Akad transaksi akan batal apabila terdapat kesalahan/kekeliruan objek, paksaan (ikrah), penipuan (tadlis). Selanjutnya, yang tidak kalah penting adalah bahwa dalam suatu akad transaksi tidak boleh ada unsur riba didalamnya.
\end{abstract}

Kata Kunci: transaksi, dekonstruksi, idealisme, pelaku, objek, akad

BISNIS, Vol. 2, No. 2, Desember 2014 


\section{A. Pendahuluan}

Kemajuan ilmu pengetahuan dan teknologi yang luar biasa saat ini, dimana terjadi lompatan-lompatan perubahan yang menakjubkan, semua itu memang telah memberikan berbagai kemudahan dalam kehidupan manusia. Namun disisi lain kemajuan tersebut tidak sedikit menjadikan manusia resah dan menghadapi masalah hidup yang semakin kompleks, sebab kemajuan ilmu pengethuan dan teknologi sering tidak diikuti dengan kemajuan yang sama dibidang spiritual dan moral. Dari sinilah kemudian pengetahuan tidak menyatu dengan nilai, kekuatan tidak menyatu dengan kebijaksanaan. Manusia berada dalam keadaan dilematis, intelektual dan moralitasnya terombang-ambing tanpa terkendali. Kondisi ini telah membuktikan ketidaksamaan (disharmoni) dalam individu dan masyarakat sehingga membuat manusia menderita dan kesepian (Maksum, 2008)

Kondisi sebagaimana yang dijelaskan di atas, seharusnya dapat dihadapi dengan mengembalikan tujuan dari sains dan teknologi bagi kebaikan kehidupan manusia dalam segala aspek, termasuk aspek spiritual dan nilai-nilai moral. Maka disinilah peran filsafat, menurut Maksum (2008) filsafat yang akan memaknai kembali landasan sains dan teknologi baik pada tataran epistemology, ontology maupun aksiologinya. Oleh karena itu filsafat harus merumuskan kembali muatan moral dan nilai bagi landasan bangunan sains modern. Sehingga dapat disebutkan bahwa fungsi filsafat adalah untuk menyelamatkan manusia dari kesesatan hidup dalam menghadapi pengaruh kemajuan dan gaya hidup materialisme; melepaskan kungkungan kegelisahan dan ketidakbermaknaan.

Dalam konteks menerapkan fungsi dari filsafat tersebut di atas, maka akuntansi sebagai bagian dari sains dan teknologi juga harus merumuskan kembali muatanmuatan moral dan nilai dalam kerangka pengetahuan akuntansi tersebut. Dalam pandangan Islam, menurut Isgiyarta (2009) terhadap akuntansi konvensional ada beberapa hal yang harus diganti dengan konsep yang sesuai dengan nilai-nilai dalam Al Quran dan Al Hadist. Salah satu upaya yang dapat dilakukan untuk merumuskan muatan moral dan nilai dalam akuntansi, yakni dengan memasukkan unsur-unsur nilai moral dalam setiap makna dari definisi akuntansi. Salah satu definisi akuntansi adalah pencatatan, penggolongan, dan pengikhtisaran dengan cara tertentu dalam ukuran moneter, transaksi, dan kejadian-kejadian yang umumnya bersifat keuangan termasuk menafsirkan hasil-hasilnya (AICPA). Selain itu, Isgiyarta (2009) mendefinisikan akuntansi Islam adalah suatu proses aktivitas jasa yang didalamnya ada aktivitas pencatatan transasksi keuangan atau peristiwa ekonomi, penggolongan, peringkasan, dan menyajikannya dalam jenis-jenis informasi yang sesuai dengan tujuan pendirian entitas; proses aktivitas tersebut 
dan informasi yang dihasilkan harus sesuai dengan nilai-nilai yang terkandung dalam Al Quran dan Al hadist. Salah satu kata kunci dari definisi tersebut adalah transaksi, dimana transaksi menjadi dasar apa yang dicatat, diikhtisar dan dilaporkan. Sehingga sangat penting untuk memastikan makna dari suatu transaksi, serta muatan nilai dan moral didalamnya, apakah suatu kejadian memenuhi kriteria transaksi atau tidak akan menentukan suatu kejadian tersebut akan diproses secara akuntansi atau tidak.

Makalah ini mencoba untuk merumuskan muatan moral dan nilai dalam lingkup makna transaksi yang merupakan dasar adanya praktik pencatatan serta proses selanjutnya dalam akuntansi. Adapun sumber utama dari muatan moral dan nilai adalah dari ajaran agama (dalam makalah ini merujuk pada ajaran agama Islam), sejalan dengan hal ini, aliran filsafat idealisme mengajarkan bahwa hakikat dunia fisik hanya dapat dipahami kaitannya dengan jiwa dan ruh. Idealisme juga didefinisikan sebagai suatu ajaran, faham atau aliran yang menganggap bahwa realitas ini terdiri atas ruh-ruh (sukma) atau jiwa, ide-ide dan pikiran atau yang sejenis dengan itu. Sehingga aliran ini merupakan aliran filsafat yang sangat penting dalam sejarah pemikiran manusia, karena segenap kaum agama dapat digolongkan kedalam penganut idealisme yang paling setia sepanjang masa. Dengan demikian dapat disimpulkan bahwa aliran filsafat idealisme menempatkan ajaran agama atau spiritualitas sebagai landasan berfikir yang utama.

Proses memberikan muatan moral dan nilai dalam lingkup makna transaksi juga sejalan dengan aliran filsafat Dekonstruksionisme, dimana menurut Derrida yang merupakan penganut aliran ini menawarkan suatu proses pemaknaan dengan cara membongkar (to dismantle) dan menganalsis secara kritis. Makna tidak dapat terlihat dalam satu kali jadi, melainkan pada waktu dan situasi yang berbeda-beda dengan makna yang berbeda-beda pula, proses dekonstruksi ini bersifat tidak terbatas (Maksum, 2008). Sebagai landasan dalam pembahasan, berikut ini akan dibahas hubungan antara ilmu, moral dan agama.

\section{B. Pembahasan}

\section{Ilmu dan Moral}

Peradaban manusia sangat dipengaruhi ilmu dan teknologi, dengan kemajuan dalam bidang bidang ini maka pemenuhan kebutuhan manusia bisa dilakukan dengan lebih cepat dan lebih mudah terkait dengan kesehatan, tranportasi, pendidikan dan komunikasi. Namun dalam kenyataannya kemajuan ilmu dan teknologi tidak selalu membawa kebaikan, tetapi juga dapat memberikan dampak yang negatif bagi kehidupan manusia. Dampak negatif ini dapat disebabkan oleh proses perkembangan ilmu dan teknologi yang mengabaikan faktor manusia 
bahkan telah menimbulkan gejala dehumanisasi bahkan kemungkinan mengubah hakikat kemanusiaan. Oleh sebab itu, ilmu yang pada hakikatnya mempelajari alam sebagaimana adanya mulai mempetanyakan hal-hal yang bersifat seharusnya; untuk apa ilmu harus dipergunakan, apakah ada batasan penjelajahan keilmuan, dan kemana arah perkembangan keilmuan. Untuk menjawab pertanyaanpertanyaan ini maka ilmuwan berpaling kepada hakikat moral. Sebenarnya sejak saat pertumbuhannya ilmu sudah terkait dengan masalah-masalah moral namun dalam perspektif yang berbeda. Secara metafisik ilmu ingin mempelajari alam sebagaimana adanya, sedangkan dipihak lain, terdapat keinginan agar ilmu mendasarkan kepada pernyataan-pernyataan (nilai-nilai) yang terdapat dalam ajaran-ajaran diluar bidang keilmuan termasuk agama (Suriasumantri, 2010).

Masalah teknologi yang mengakibatkan proses dehumanisasi sebenarnya lebih merupakan masalah kebudayaan daripada masalah moral. Artinya ketika dihadapkan pada ekses teknologi yang bersifat negative, maka masyarakat harus menentukan teknologi mana yang akan dipergunakan dan teknologi mana yang tidak. Secara konseptual maka hal ini berarti bahwa suatu masyarakat harus menetapkan strategi pengembangan teknologinya agar sesuai dengan nilai-nilai budaya yang dijunjungnya.

Para ilmuwan terbagai kedalam dua pendapat ketika dihadapkan dengan masalah moral dalam menghadapi ekses ilmu dan teknologi yang bersifat merusak. Golongan pertama menginginkan bahwa ilmu harus bersifat netral terhadap nilainilai baik secara ontologis maupun aksiologis. Dalam hal ini tugas ilmuwan adalah menemukan pengetahuan dan terserah kepada orang lain untuk mempergunakannya, apakah pengetahuan itu dipergunakan untuk tujuan yang baik, ataukah dipergunakan untuk tujuan yang buruk.. Golongan kedua sebaliknya, berpendapat bahwa netralitas ilmu terhadap nilai-nilai hanyalah terbatas pada metafisik keilmuan, sedangkan dalam penggunaannya, bahkan pemilihan objek penelitian, maka kegiatan keilmuan harus berlandaskan asas-asas moral.

Golongan pertama ingin melanjutkan tradisi kenetralan ilmu secara total, sedangkan golongan kedua mencoba menyesuaikan kenetralan ilmu secara pragmatis berdasarkan perkembangan ilmu dan masyarakat. Golongan kedua mendasarkan pendapatnya pada beberapa hal, diantaranya adalah ilmu secara faktual telah dipergunakan secara destruktif oleh manusia, berdasarkan hal tersebut maka golongan kedua berpendapat bahwa ilmu secara moral harus ditujukan untuk kebaikan manusia tanpa merendahkan martabat atau mengubah hakikat kemanusiaan. 
Masalah moral tidak bias dilepaskan dengan tekad manusia untuk menemukan kebenaran, sebab untuk menemukan kebenaran dan mempertahankannya diperlukan keberanian moral. Tanpa landasan moral maka ilmuwan mudah sekali tergelincir dalam melakukan penyimpangan intelektual. Penalaran secara rasional yang telah membawa manusia mencapai harkatnya seperti sekarang ini kan berganti dengan proses rasionalisasi yang bersifat mendustakan kebenaran (Suriasumantri, 2010).

\section{Agama, Ilmu dan Masa Depan Manusia}

Agama mendorong umatnya untuk menuntut ilmu, hamper semua kitab suci menganjurkan umatnya untuk mencari ilmu sebanyak mungkin. Agama dan ilmu dalam beberapa hal berbeda, namun pada sisi tertentu memiliki kesamaan. Agama lebih mengedepankan moralitas dan menjaga tradisi yang sudah mapan (ritual) cenderung eksklusif dan subjektif. Sementara ilmu selalu mencari yang baru, tidak terlalu terikat dengan etika, progresif, bersifat inklusif dan objektif. Kendati agama dan ilmu berbeda, keduanya memiliki persamaan yakni bertujuan memberi ketenangan dan kemudahan bagi manusia. Karakteristik ilmu dan agama tidak selalu harus dilihat dalam konteks yang berseberangan, tetapi juga perlu dipikirkan bagaimana keduanya bersinergi dalam memabantu kehidupan manusia yang lebih layak.

Agama merupakan faktor utama dalam mewujudkan pola persepsi dunia bagi manusia, jadi persepsi tersebut akan dapat mempengaruhi perkembangan dunia, pada akhirnya akan menentukan jalannya sejarah dalam kehidupan manusia. Selain itu persepsi yang dimiliki oleh manusia akan menentukan pula caranya dalam memposisikan dirinya di dunia ini. Dalam kerangka itu, agama dan ilmu memiliki kesamaan, yakni sama-sama mendesain masa depan manusia. Desain agama lebih jauh dan abstrak sedangkan ilmu dan teknologi lebih pendek dan konkret. Desain agama untuk memberikan ketenangan hidup setelah hidup, sedangkan desain ilmu dan teknologi untuk hidup masa depan di dunia ini.

Ilmu dan teknologi dapat menciptakan sesuatu yang tidak diprediksi sebelumnya, saat ini ilmu dan teknologi telah mengalami degradasi nilai, jika teknologi dijadikan tujuan dan cita-cita maka pada gilirannya peradaban teknologi akhirnya berubah menjadi kekuasaan yang membelenggu manusia sendiri. Dalam pandangan agama, ilmu dan teknologi bukan merupakan aspek kehidupan umat manusia yang tertinggi. Serta juga bukan merupakan puncak kebudayaan dan peradaban umat manusia di dalam evolusinya mencapai kesempurnaan hidup. Banyak kaum rasionalis yang materialis menganggap bahwa abad modern, abad 
ilmu pengetahuan dan teknologi sekarang adalah puncak dari peradaban dan kebudayaan manusia. Karena dengan akalnya manusia modern dapat menghasilkan ilmu pengetahuan danteknologi yang sangat mengagumkan, dan menganggap manusia zaman dahulu adlah lebih rendah peradaban dan kebudayaannya karena terlalu diliputi oleh kehidupan yang tidak rasional, takhayul, dan terbelenggu oleh kepercayaan agama yang dogmatis.

Ilmu pengetahuan dan teknologi memakai "rasio" atau akal, sedangkan kejiwaan agama memakai "intuisi" atau wahyu sebagai sarana masing-masing untuk membuktikan kebenarannya dan menghayati hakikatnya. Ilmu pengetahuan hingga kini dianggap sebagai pengawal kemajuan manusia yang akhir-akhir ini secara umum banyak diserang sebagai pembawa berbagai macam ketimpangan dan pencemaran fisik, biologi, sosial dan budaya.

Sinergi agama dan ilmu harus dilakukan demi terwujudnya keseimbangan peradaban manusia. Oleh sebab itu ilmu dan teknologi tidak harus dilihat dari aspek yang sempit, tetapi harus dilihat dari tujuan jangka panjang dan untuk kepentingan kehidupan yang lebih abadi. Maka disinilah perlunya memberikan muatan nilai dan moral yang bersumber dari agama dalam setiap konsep, pengembangan dan penerpan ilmu dan teknologi.

\section{Definisi Transaksi}

Pengertian transaksi menurut Skousen (2007:71) adalah pertukaran barang dan jasa antara (baik individu, perusahaan-perusahaan dan organisasi lain) kejadian lain yang mempunyai pengaruh ekonomi atas bisnis. Sedangkan menurut Bastian (2007:27) definisi transaksi adalah pertemuan antara dua belah pihak ( penjual dan Pembeli) yang saling menguntungkan dengan adanya data/bukti/dokumen pendukung yang dimasukkan kedalam jurnal setelah melalui pencatatan.

Selain itu, pengertian transaksi menurut Wiyono (2005:12) adalah suatu kejadian ekonomi atau keuangan yang melibatkan paling tidak dua pihak (seseorang dengan seseorang atau beberapa orang lainnya) yang saling melakukan pertukaran, melibatkan diri dalam perserikatan usaha pinjam meminjam dan lain-lain atas dasar suka sama suka ataupun atas dasar suatu ketetapan hukum/syariat yang berlaku. Adapun pengertian transaksi menurut Kamus Besar Bahasa Indonesia (KBBI) adalah persetujuan jual beli dalam perdagangan antara pihak pembeli dan penjual.

Dari beberapa pengertian transaksi yang dikutif dari beberapa sumber di atas, terlihat bahwa definisi tersebut hanya terkait dengan teknis terjadinya suatu 
transaksi yang dimaknai dari aspek kejadian eknonomi/bisnis semata, belum ada muatan nilai dan moral secara eksplisit.

\section{Transaksi dalam Konsep Islam}

Pengertian transaksi menurut Zulkifli (2003:10) secara umum transaksi dapat diartikan sebagai kejadian ekonomi/ keuangan yang melibatkan paling tidak 2 pihak (seseorang dengan seseorang atau beberapa orang lainnya) yang saling melakukan pertukaran, melibatkan diri dalam perserikatan usaha, pinjam meminjam atas dasar sama-sama suka ataupun atas dasar suatu ketetapan hukum atau syariah yang berlaku. Dalam sistem ekonomi Islam, transaksi harus dilandasi oleh aturan hukum-hukum Islam (syariah) karena transaksi adalah manifestasi amal manusia yang bernilai ibadah dihadapan Allah, yang dapat dikategoriakn menjadi 2 yaitu transaksi halal dan haram."

Penyebab terlarangnya sebuah transaksi adalah disebabkan faktor-faktor berikut ini :

a. Haram zatnya / haram li-dzatihi

b. Haram selain zatnya / haram li-ghairihi

c. Tidak sah/lengkap akadnya

\subsection{Haram Zatnya}

a. Transaksi dilarang karena objek (barang/jasa) yang ditransaksikan juga terlarang. Misalnya : minuman keras, daging babi, bangkai, dll.

b. Jadi transaksi jual beli tersebut adalah haram, walaupun akad jual-belinya sah

\section{2. Haram Selain Zatnya}

a. Melanggar Prinsip "An Taraddin Minkum"

An Taraddin Minkum maksudnya adalah transaksi dalam Islam harus berdasarkan prinsip kerelaan antara kedua belah pihak (sama-sama ridha). Para pihak harus mempunyai informasi yang seimbang (complete information)

Assymetric information atau unknown to one party yang dalam bahasa fiqih disebut TADLIS adalah transaksi dimana salah satu pihak tidak mengetahui informasi yang diketahui pihak lain

Tadlis dapat terjadi dalam 4 hal, yakni :

- Kuantitas, contohnya pedagang mengurangi takaran

- Kualitas, contohnya pedagang menyembunyikan cacat barang yang ditawarkannya 
- Harga (ghaban), contohnya pedagang menaikkan harga barang di atas harga pasar karena ketidaktahuan pembeli akan harga pasar

- Waktu penyerahan, contohnya pedagang yang berjanji akan mengirimkan barangnya dalam dua hari padahal dia tahu bahwa hal tersebut tidak mungkin bisa dipenuhinya

b. Melanggar Prinsip "La Tazhlimuna Wa La Tuzhlamun”

La tazhlimuna wa la tuzhlamun maksudnya jangan menzalimi dan jangan dizalimi.

Praktek-praktek yang melanggar prinsip ini di antaranya :

口 Rekayasa Pasar dalam supply (Ikhtikar), terjadi bila produsen mengambil keuntungan di atas normal dengan cara mengurangi supply agar harga produk yang dijualnya naik. Ikhtikar terjadi bila syarat di bawah ini terpenuhi :

$>$ Mengupayakan adanya kelangkaan barang baik dengan menimbun stock atau mengenakan entry-bariers

$>$ Menjual dengan harga yang lebih tinggi pada saat terjadi kelangkaan barang

$>$ Mengambil keuntungan yang lebih tinggi dibandingkan keuntungan sebelum komponen 1 \& 2 dilakukan

- Rekayasa Pasar dalam Demand (Ba'i Najasy), terjadi bila produsen menciptakan permintaan palsu seolah-olah ada banyak permintaan sehingga harga jual produk tersebut akan naik. Contohnya: dalam bursa saham, bursa valas, dll.

- Taghrir (Gharar), adalah situasi dimana terjadi incomplete information karena adanya ketidakpastian dari kedua belah pihak yang bertransaksi. Gharar ini terjadi bila kita mengubah sesuatu yang seharusnya pasti menjadi tidak pasti. Gharar juga dapat terjadi dalam 4 hal, yaitu :

Kuantitas, contohnya ijon

$>$ Kualitas, contohnya membeli anak sapi yang masih dalam kandungan induknya

> Harga, contohnya pembiayaan murabahah rumah 1 tahun margin 20\%, 2 tahun margin $40 \%$ yang kemudian disepakati nasabah tanpa menentukan pilihannya 1 atau 2 tahun

$>$ Waktu penyerahan, contohnya menjual barang yang hilang yang belum jelas kapan akan diketemukan dan kapan akan dapat diserahkan

- Riba, dalam ilmu fiqih dikenal 3 jenis riba, yaitu :

Riba Fadl (riba buyu), yaitu riba yang timbul akibat pertukaran barang sejenis yang tidak memenuhi kriteria kualitasnya (mistlan bi mistlin), 
sama kuantitasnya (sawa-an bi sawa-in), dan sama waktu penyerahannya (yadan bi yadin). Hadits Rasulullah SAW:

"Dari Abu Said Al-Khudri r.a., Rasul SAW. bersabda: Transaksi pertukaran emas dengan emas harus sama takaran, timbangan dan tangan ke tangan (tunai), kelebihannya adalah riba; perak dengan perak harus sama takaran dan timbangan dan tangan ke tangan (tunai), kelebihannya riba; gandum dengan gandum harus sama takaran dan timbangan dan tangan ke tangan (tunai), kelebihannya riba; tepung dengan tepung harus sama takaran dan timbangan dan tangan ke tangan (tunai), kelebihannya riba; korma dengan korma harus sama takaran dan timbangan dan tangan ke tangan (tunai), kelebihannya riba; garam dengan garam harus sama takaran dan timbangan dan tangan ke tangan (tunai), kelebihannya riba." (Riwayat Muslim) Di luar keenam jenis barang ini dibolehkan asalkan dilakukan penyerahannya pada saat yang sama. Rasul SAW bersabda :

"Jangan kamu bertransaksi satu dinar dengan dua dinar; satu dirham dengan dua dirham; satu sha' dengan dua sha' karena aku khawatir akan terjadinya riba' (al-rama). Seorang bertanya: 'wahai Rasul, bagaimana jika seseorang menjual seekor kuda dengan beberapa ekor kuda dan seekor unta dengan beberapa ekor unta?' Jawab Nabi SAW: "Tidak mengapa, asal dilakukan dengan tangan ke tangan (langsung)." (HR Muslim).

Contoh riba fadl dalam perbankan adalah dalam transaksi jual beli valuta asing yang tidak dilakukan dengan cara tunai (spot)

> Riba Nasi'ah (riba duyun), yaitu riba yang timbul akibat transaksi yang tidak memenuhi kriteria untung muncul bersama resiko (al ghunmu bil ghurmi) dan hasil usaha muncul bersama biaya (al kharaj bi dhaman).

Riba Nasi'ah muncul karena adanya perbedaan, perubahan atau tambahan antara barang yang diserahkan heari ini dengan barang yang diserahkan kemudian. Jadi al ghunmu (untung) muncul tanpa adanya al ghurmi (resiko), al kharaj (hasil usaha) muncul tanpa adanya dhaman (biaya); yang mana al ghunmu dan kharaj muncul hanya dengan berjalannya waktu.

Contoh riba nasi'ah yaitu pembayaran bunga kredit, bunga deposito, tabungan, giro, dll.

> Riba Jahiliyah, adalah hutang yang dibayar melebihi dari pokok pinjaman, karena si peminjam tidak mampu mengembalikan dana pinjaman pada waktu yang telah ditetapkan. Hal ini dilarang karena terjadi pelanggaran kaidah

> "Kullu Qardin Jarra Manfa'ah Fahuwa Riba" (setiap pinjaman yang mengambil manfaat adalah riba). 
Contoh riba jahiliyah adalah dalam pengenaan bunga pada transaksi kartu kredit yang tidak dibayar penuh tagihannya

\subsection{Tidak Sah/Lengkap Akadnya}

Transaksi dapat dikatakan tidak sah dan/atau tidak lengkap akadnya bila terjadi salah satu (atau lebih) faktor-faktor berikut ini:
A. Rukun dan Syarat tidak terpenuhi
B. Terjadi Ta'alluq
C. Terjadi "two in One"

\section{A. Rukun dan Syarat}

Rukun adalah sesuatu yang wajib ada dalam suatu transaksi, yang terdiri dari 3 hal, yaitu :

1). Pelaku, bisa berupa penjual-pembeli, penyewa-pemberi sewa, penerima upah-pemberi upah.

2). Objek, bisa berupa barang dan jasa

3). Ijab-Kabul, dalam terminologi fiqih maksudnya adalah adanya kesepakatan antara kedua belah pihak yang bertransaksi. Berkaitan dengan kesepakatan, akad akan batal apabila terdapat :

o Kesalahan/kekeliruan objek

o Paksaan (ikrah)

o Penipuan (tadlis)

Syarat adalah sesuatu yang keberadaannya melengkapi rukun. Contohnya adalah bahwa pelaku transaksi haruslah orang yang cakap hukum (mukallaf). Bila rukun telah terpenuhi, tetapi syarat tidak dipenuhi, rukun menjadi tidak lengkap sehingga transaksi tersebut menjadi fasid (rusak)

Syarat bukanlah rukun, jadi tidak boleh dicampuradukkan. Keberadaan syarat juga tidak boleh:

- Menghalalkan yang haram

- Mengharamkan yang halal

- Menggugurkan rukun

- Bertentangan dengan rukun

- Mencegah berlakunya rukun

\section{B. Ta'alluq}

Ta'aluq terjadi bila kita dihadapkan pada dua akad yang saling dikaitkan, dimana berlakunya akad 1 tergantung pada akad 2. Transaksi di atas haram, 
karena ada persyaratan. Penerapan syarat ini mencegah terpenuhinya rukun. Dalam terminologi fiqih, kasus ini disebut dengan bai' al-'inah

\section{C. "Two in one"}

Two in one adalah kondisi dimana suatu transaksi diwadahi oleh dua akad sekaligus sehingga terjadi ketidakpastian (gharar) mengenai akad mana yang harus digunakan/berlaku. Dalam terminologi fiqih, kejadian ini disebut dengan shafqatain fi al-shafqah

Two in one terjadi bila semua dari ketiga faktor di bawah ini terpenuhi:

- Objek sama

- Pelaku sama

- Jangka waktu sama

Bila salah satu saja dari faktor tersebut tidak terpenuhi, maka two in one tidak terjadi, dengan demikian akad menjadi sah.

Contoh dari two in one adalah transaksi lease and purchase (sewa-beli). Dalam transaksi ini terjadi gharar dalam akad, kareda ada ketidakjelasan akad mana yang berlaku: akad beli atau akad sewa. Karena itulah maka transaksi sewa-beli ini diharamkan.

\section{Muatan Nilai dan Moral dalam Makna Transaksi}

Dalam pandangan Islam suatu transaksi dapat dikatakan sah jika memenuhi ketentuan rukun dan syaratnya. Rukun dalam suatu transaksi bersifat wajib, oleh sebab itu tidak boleh ada pelanggaran terhadap rukun yang harus dipenuhi. Pertama, pelaku transaksi, dalam suatu transaksi harus jelas keberadannya (pembeli/penjual/penyewa/penerima sewa/pemberi upah/penerima upah) serta memenuhi kriteria diantaranya adalah berakal. Selain itu menurut syariat Islam pelaku transaksi tidak boleh melanggar prinsip menzhalimi dan dizhalimi, seperti tidak bolehnya pelaku transaksi melakukan rekayasa pasar baik dari aspek penawaran maupun permintaan. Selanjutnya pelaku transaksi juga tidak diperbolehkan menciptakan ketidakpastian (gharar) terkait dengan harga, kualitas, kuantitas serta waktu dalam bertransaksi.

Kedua, objek transaksi, objek dalam suatu transaksi dapat berupa barang atau jasa. Sesuai rukun transaksi dalam syriat Islam, objek transaksi inipun harus jelas keberiadaannya serta tidak boleh melanggar prinsip halal dan haramnya. Suatu transaksi menjadi terlarang jika objek yang ditransaksikan (barang/jasa) mengandung unsur hal-hal yang diharamkan secara zatnya. Selain itu, objek yang ditransaksikan juga tidak boleh mengandung ketidakpastian dari segi harga, kualitas, kuantitas dan waktu. 
Ketiga, akad transaksi, dalam terminologi fiqih maksudnya adalah adanya kesepakatan antara kedua belah pihak yang bertransaksi. Berkaitan dengan kesepakatan, akad akan batal apabila terdapat kesalahan/kekeliruan objek, paksaan (ikrah), penipuan (tadlis). Tadlis adalah transaksi dimana salah satu pihak tidak mengetahui informasi yang diketahui pihak lain. Tadlis dapat terjadi dalam 4 hal, yakni harga, kualitas, kuatitas dan waktu. Selanjutnya, yang tidak kalah penting adalah bahwa dalam suatu akad transaksi tidak boleh adanya unsur riba didalamnya.

Suatu transaksi akan menjadi sempurna jika memenuhi syarat-syaratnya, karena syarat sifatnya adalah melengkapi rukun dalam transaksi. Namun demikian, keberadaan syarat dalam suatu transaksi tidak boleh; menghalalkan yang haram, mengharamkan yang halal, menggugurkan rukun, bertentangan dengan rukun, serta mencegah berlakunya rukun.

\section{Kesimpulan}

Berdasarkan penjelasan di atas, maka makna transaksi dalam pandangan Islam dapat di dekonstruksi menjadi suatu akad (tentang kejadian ekonomi) terhadap barang/jasa yang melibatkan dua pihak atau lebih, dimana baik akad, objek maupun pelakunya harus memenuhi rukun dan syarat transaksi sesuai dengan syariat Islam. Bagi institusi yang berasaskan syariat Islam, baik perusahaan, organisasi nirlaba maupun instansi pemerintah, seharusnya menerapkan kriteria transaksi yang sesuai dengan syariat Islam dalam aktivitas bisnis atau aktivitas operasionalnya. Sehingga pihak-pihak yang terlibat dalam suatu transaksi seperti pegawai, bendahara dan tenaga pembukuan akuntansi harus benar-benar memahami kriteria transaksi ini, supaya setiap transaksi (jual/beli/ sewa/menyewa/ pembayaran/penerimaan) yang dilakukan tidak melanggar syariat Islam. Selain itu, dengan diterapkannya kriteria transaksi yang sesuai dengan syariat Islam ini mempunyai konsekuensi secara praktis pada bentuk dan isi/format bukti transaksi yang digunakan oleh perusahaan/ organisasi/ instansi pemerintah, misalnya dalam setiap bukti transaksi harus terdapat format pengecekan kesesuaian harga, kuantitas dan kualitas, dan waktu penyerahan objek yang ditransaksikan. Dampak selanjutnya adalah pada saat pemeriksaan atau audit dilaksanakan, maka dalam hal ini auditor juga harus menguji kesesuaian bukti transaksi yang dilaporkan apakah juga telah sesuai dengan kriteria transaksi yang sesuai dengan syariat Islam. 


\section{DAFTAR PUSTAKA}

Bakhtiar, Amsal. 2011. Filsafat Ilmu. Jakarta: RajaGrafindo Persada.

Isgiyarta, Jaka. 2012. Teori Akuntansi dan Laporan Keuangan Islam. Semarang: Badan Penerbit Universitas Diponegoro.

Maksum, Ali. 2014. Pengantar Filsafat: Dari Masa klasik hingga Postmodernisme. Jogjakarta; Ar-Ruzz Media.

Skousen, Smith. 2007. Pengantar Akuntansi Keuangan.

Suriasumantri, Jujun S. 2009. Filsafat Ilmu: Sebuah Pengantar Populer. Jakarta: pustaka Sinar Harapan.

Zulkifli, Sunarto. 2003. Dasar-dasar Akuntansi Perbankan Syariah. 